\title{
Methemoglobinaemia with chronic phenazopyridine ingestion
}

\author{
Akanksha Agrawal, ${ }^{1}$ Nathan Davis, ${ }^{1}$ Ronan Hsieh, ${ }^{1}$ Seth Stallard ${ }^{2}$
}

${ }^{1}$ Internal Medicine, Albert Einstein Medical Center, Philadelphia, Pennsylvania, USA ${ }^{2}$ Emergency Medicine, Albert Einstein Medical Center, Philadelphia, Pennsylvania, USA

\section{Correspondence to} Dr Akanksha Agrawal, akanksha21agr@gmail.com

Accepted 18 January 2019

\section{DESCRIPTION}

A 55-year-old Caucasian woman with history of multiple sclerosis and neurogenic bladder with suprapubic catheter presented to the emergency department with suprapubic pain and lethargy for 2 weeks. She was hypoxic, saturating $88 \%$ on room air. Her examination was notable for subtle bluish discolouration of the lips. Her urine was amber coloured (figure 1A), and blood was brownish-black colour (figure 1B). She was taking phenazopyridine $200 \mathrm{mg}$ three times a day regularly for the last 5 months for urinary discomfort. With significant clues from her hypoxia, chronic phenazopyridine ingestion, colour of urine and blood, her methemoglobin level (MetHb) using co-oximeter and blood gas analyser was checked which resulted at 9.3\% (normal level 1\%-3\%). She was diagnosed with acquired methemoglobinaemia and advised to stop the medication. Her hypoxia improved and methemoglobin level decreased to $5 \%$ the following day. She felt symptomatically better.

Phenazopyridine is a commonly prescribed medication with urinary anaesthetic properties. The use of phenazopyridine for symptomatic relief of pain, burning, urgency and frequency is recommended to be limited to 2 days. It is a known cause of acquired methemoglobinaemia, though only a handful of cases have been reported. ${ }^{1}$ We describe a case of acquired methemoglobinaemia secondary to chronic ingestion phenazopyridine for 5 months. Methemoglobinaemia results when iron in the haemoglobin

A

B

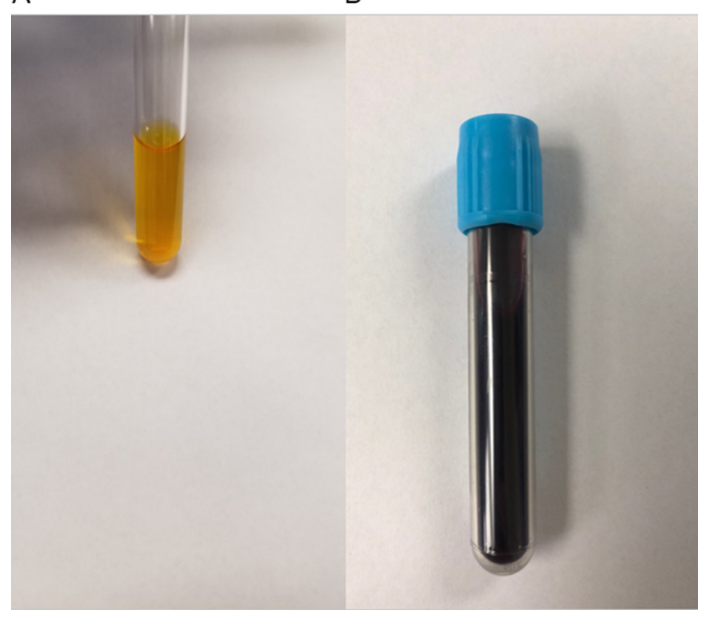

Figure 1 (A) The amber-coloured urine suggesting phenazopyridine ingestion. (B) Presence of dark brownish-black blood raising suspicion for methemoglobinaemia. is oxidised from ferrous to ferric state. Ferric iron has lower affinity for oxygen, thereby more oxygen binds to ferrous form in methemoglobin, resulting in shift of oxygen haemoglobin dissociation curve to the left. ${ }^{2}$ If symptomatic or severe, methemoglobinaemia is usually treated with methylene blue. It is important to know that phenazopyridine is also notorious in causing sulfhaemoglobinaemia, and distinction of methemoglobinaemia from sulfhaemoglobinaemia has value in treatment strategy. ${ }^{3}$ While methemoglobinaemia would respond with decreasing MetHb levels with methylene blue, sulfhaemoglobinaemia is not reversible (cannot be reconverted to functional haemoglobin) and its management often requires blood transfusion, if severe. ${ }^{3}$ In our patient, stopping the offending agent decreased the methemoglobin level. Most available co-oximeters are not able to differentiate between MetHb and SulfHb, leading to false-positive diagnosis of methemoglobinaemia. More sophisticated methods of detection and differentiation are needed. It is critically important for an emergency physician and medicine physician to use subtle diagnostic clues like bluish discolouration, change in urine colour and blood colour to appropriately diagnose such medical condition. Our case, therefore, highlights the importance of thorough history and physical examination for a clinician to be an astute diagnostician.

\section{Learning points}

Acquired methemoglobinaemia is a rare occurrence and can be due to various medications including phenazopyridine.

- A thorough history and physical examination is crucial for a diagnostician.

- The presence of bluish discolouration of lips, chocolate-coloured blood and history of intake of phenazopyridine pointed towards a diagnosis of methemoglobinaemia.

Contributors AA, ND, RH and SS had substantial contributions to the conception, design of the work, the acquisition, analysis and interpretation of data; was involved in drafting the work or revising it critically for important intellectual content; gave final approval of the version published; is accountable for all aspects of the work in ensuring that questions related to the accuracy or integrity of any part of the work are appropriately investigated and resolved.

Funding The authors have not declared a specific grant for this research from any funding agency in the public, commercial or not-for-profit sectors.

Competing interests None declared. 
Patient consent for publication Not required.

Provenance and peer review Not commissioned; externally peer reviewed.

\section{REFERENCES}

1 Banimahd F, Loo T, Amin M, et al. A rare but important clinical presentation of induced methemoglobinemia. West J Emerg Med 2016;17:627-9.

Copyright 2019 BMJ Publishing Group. All rights reserved. For permission to reuse any of this content visit https://www.bmj.com/company/products-services/rights-and-licensing/permissions/

BMJ Case Report Fellows may re-use this article for personal use and teaching without any further permission.

Become a Fellow of BMJ Case Reports today and you can:

- Submit as many cases as you like

- Enjoy fast sympathetic peer review and rapid publication of accepted articles

Access all the published articles

- Re-use any of the published material for personal use and teaching without further permission

For information on Institutional Fellowships contact consortiasales@bmjgroup.com

Visit casereports.bmj.com for more articles like this and to become a Fellow
Shahani L, Sattovia S. Acquired methaemoglobinaemia related to phenazopyridine ingestion. BMJ Case Rep 2012;2012:bcr2012006756.

3 Askew SW, Baranoski GVG. On the dysfunctional hemoglobins and cyanosis connection: practical implications for the clinical detection and differentiation of methemoglobinemia and sulfhemoglobinemia. Biomed Opt Express 2018;9:3284-305. 